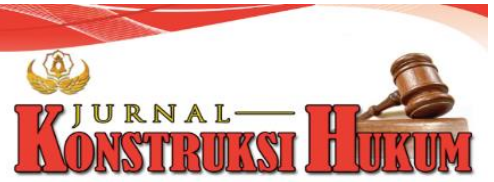

\title{
PERJANJIAN KREDIT BANK DENGAN JAMINAN BORGTOCHT (PERORANGAN)
}

\author{
I Gusti Ngurah Bagus Denny Hariwijaya, I Nyoman Putu Budiartha, I Ketut Widia \\ Fakultas Ilmu Hukum Universitas Warmadewa, Denpasar - Bali, Indonesia
}

\begin{abstract}
Abstrak
Kemajuan zaman yang sangat cepat dipengaruhi oleh perkembangan kebutuhan setiap anggota masyarakat dan cara pemenuhan ekonomi setiap anggota masyarakat. Kejadian ini memerlukan kehadiran suatu aturan jaminan kredit sebagai tempat untuk memperluas suatu usaha baik yang memiliki badan hukum dan perorangan. Pemberian ruang akan kredit membutuhkan suatu jaminan demi kepentingan keamanan. Pemberian kredit memerlukan suatu jaminan seperti rumah, tanah, mobil, saham, dan aset lainnya adalah demi kepentingan keamanan pemberian kredit tersebut dan untuk menjauhi resiko apabila seorang debitur tidak dapat memenuhi kewajibannya. Dari kepastian tersebut Bank dimungkinkan untuk memberikan kredit dengan jaminan perorangan, tetapi Bank seharusnya mempunyai keyakinan atas kebolehan dan kepandaian debitur untuk melunasi hutangnya. Berdasarkan latar belakang tersebut, penelitian ini dilakukan dengan tujuan mendeskripsikan bagaimana akibat hukum yang timbul dari perjanjian kredit yang melibatkan pihak ketiga sebagai penjamin. Penelitian ini didesain dengan menggunakan pendekatan yuridis normatif. Hasil penelitian ini menunjukkan bahwa akibat hukum yang timbul dari perjanjian kredit yang melibatkan pihak ketiga sebagai penjamin, yaitu: pertama, seorang debitur dapat dituntut oleh penanggung yang telah membayar hutangnya kreditur. Penanggungan itu bisa terjadi dengan sepengetahuan atau tanpa sepengetahuan debitur itu sendiri. Kedua, penanggung mempunyai hak menuntut biaya ganti rugi dan bunga. Ketiga, pihak kreditur dan pihak penanggung harus memperhatikan hak-hak dan kewajiban tertentu. Terakhir, penanggung atau pihak ketiga diberikan hak untuk membagi hutangnya, yaitu pada waktu digugat untuk pemenuhan, dapat menuntut bagianbagian dari pihak mereka sebagai penanggung.
\end{abstract}

Kata Kunci: Jaminan Borgtocht; Kredit Bank; Perjanjian

\begin{abstract}
The rapid progress of the times is influenced by the development of the needs of every member of society and the ways of fulfilling the economy of each member of society. This incident requires the presence of a credit guarantee regulation as a place to expand a business that has both a legal entity and an individual. Granting space for credit requires a guarantee for the sake of security. Lending requires a guarantee such as a house, land, car, shares, and other assets for the sake of security for the credit extension and to avoid risks if a debtor cannot fulfill his obligations. From this certainty, it is possible for the Bank to provide credit with individual guarantees, but the Bank should have confidence in the ability and intelligence of the debtor to repay his debt. Based on this background, this research was conducted with the aim of describing the legal consequences arising from a credit agreement involving a third party as a guarantor. This study was designed using a normative juridical approach. The results of this study indicated that the legal consequences arising from a credit agreement involving a third party as a guarantor, namely: first, a debtor can be sued by an insurer who has paid the creditor's debt. The coverage can occur with the knowledge or without the knowledge of the debtor himself. Second, the insurer has the right to demand compensation and interest. Third, creditors and insurers must pay attention to certain rights and obligations. Finally, the insurer or third party is given the right to share the debt, that is, when sued for the fulfillment, can claim shares from their party as the guarantor.
\end{abstract}

Keywords: Borgtocht Guarantee; Bank Credit; Agreement

\section{PENDAHULUAN}

Hukum merupakan salah satu norma atau peraturan yang dibuat oleh masyarakat, lahir dari masyrakat, dan untuk masyarakat. Ini yang disebut juga sebagai hukum kebiasaan. Hukum bersistem dari sebagian peraturan-peraturan yang mengatur tentang tingkah laku orang-orang sebagai anggota 
masyarakat. Hukum bermaksud untuk menerbitkan tata tertib di antara anggota masyarakat yang berkepentingan. Dalam hubungan keperdataan, secara menjurus yang melekat dalam permasalahan perjanjian, pada umumnya yang menjadi pokok penting adalah kepercayaan masing-masing para pihak. Kepercayaan para pihak diciptakan sebagai kesepakatan dalam bentuk perjanjian. Dengan begitulah dapat dipastikan bahwa kehakikian perjanjian baru diucapakan sah kalau ada kesepakatan dari para pihak yang melakukan perjanjian. Kata sepakat ini wajib dilakukan oleh mereka yang sudah cakap hukum dan tidak melanggar norma atau peraturan yang sudah ada dalam Kitab Undang-Undang Hukum Perdata.

Masyarakat pada zaman dahulu dalam membentuk suatu perjanjian apapun kebanyakan dilaksanakan dalam bentuk lisan atau ucapan langsung atau dalam bentuk tidak tertulis. Hal ini terjadi karena dilandasi oleh rasa saling mempercayai bahwa setiap anggota masyarakat akan bersifat atau berperilaku jujur. Kondisi semacam ini sampai sekarangpun masih sering terjadi pada masyarakat di pedesaan yang pola pikirnya masih sangat sederhana dan bersifat lugu. Perjanjian yang dilakukan secara lisan tidak jarang menimbulkan kesulitan apabila terjadi perselisihan di antara mereka yang membuat perjanjian tersebut.

Selain kesulitan dalam mendapatkan alat bukti, perjanjian lisan juga menyumbang kesulitan dalam mencari kebenaran materil dari perjanjian tersebut. Lebih sulit lagi apabila perjanjian tersebut dibuat oleh kedua belah pihak tanpa adanya saksi-saksi. Kenyataan keadaan semacam ini agak sulit menentukan kepastian hukumnya sehingga tidak jarang kalau perselisihan sampai tingkat pengadilan, sering salah satu pihak merasa puas akan keputusan yang dijatuhkan oleh pihak berwewenang.

Pada jaman yang sudah maju sekarang umumnya setiap perjanjian yang dibuat sudah dalam bentuk tertulis, baik yang dibuat dengan akta otentik maupun yang dibuat dengan akta di bawah tangan. Walapun demikian, pelanggaran atau penyimpangan dari ketentuan yang telah ditetapkan masih saja terjadi, sehingga pelaksanaan perjanjian yang dikehendaki dapat dilaksanakan sebagaimana mestinya bisa batal secara keseluruhan.

Jadi, dari apa yang dikemukakan di atas dapat dikatakan bahwa setiap perjanjian itu dibuat dalam bentuk tertulis dan bentuk lisan. Namun, bentuk lisan belum tentu akan dapat berjalan semulus dan sesuai pada waktu rencana perjanjian tersebut dibuat dan disepakati. Perihal ketentuan-ketentuan yang mengatur tentang perjanjian terdapat dalam ketentuan KUHPerdata Buku III tentang Perikatan "Kata perikatan ini mempunyai arti yang lebih luas daripada perkataan Perjanjian" (Aman, 1985).

Seperti yang telah disinggung pula di atas bahwa perkembangan zaman atau perubahan keadaan juga dipengaruhi oleh perkembangan kebutuhan dan cara pemenuhan tersebut setiap anggota masyarakat yang bersangkutan. Didalam pemenuhan kebutuhan dalam bidang perekonomian akan memerlukan adanya keberadaan suatu lembaga jaminan kredit, sebagai sarana untuk memperbesar atau memperluas suatu usaha baik yang bersifat badan hukum dan perorangan. Pemberian fasilitas kredit memerlukan suatu jaminan demi kepentingan keamanan pemberian kredit tersebut, hal ini penting untuk menghindari adanya resiko apabila seorang debitur tidak dapat memenuhi kewajibannya.

"Karena perkembangan ekonomi dan perdagangan akan diikuti oleh perkembangan akan kebutuhan akan kredit dan pemberian fasilitas akan kredit ini memerlukan demi keamanan pemberian kredit tersebut" (Sofwan \& Indonesia. Badan Pembinaan Hukum Nasional, 1980).

Jadi jaminan atau anggunan di dalam perjanjian kredit mempunyai makna yang sangat penting. Selanjutnya disebutkan dalam UU No. 10 tentang Perbankan dalam pasal 8 "Dalam mememberikan kredit, Bank Umum wajib mempunyai keyakinan atas kemampuan dan kesanggupan debitur untuk melunasi hutangnya sesuai dengan yang diperjanjikan" dan sesuai dengan UU No.10 Tahun 1998 tentang Perubahan Atas UU Tentang Perbankan.

Dari ketentuan tersebut Bank dapat dimungkinkan untuk memberikan kredit dengan jaminan perorangan. Namun, Bank harus mempunyai keyakinan atas kemampuan dan kesanggupan debitur untuk melunasi hutangnya. Pemberian kredit dengan jaminan pihak ketiga haruslah dinyatakan secara tegas dalam bentuk tertulis agar masing-masing pihak mengetahui apa yang menjadi hak-haknya, dan dalam perlunasan hutangnya nanti sesuai dengan apa yang telah diperjanjikan. Jadi keberadaan lembaga jaminan kredit ini sangatlah erat kaitannya dengan lalu lintas hubungan keperdataan dalam dunia usaha, terutama yang menyangkut masalah perjanjian hutang piutang.

Penelitian terdahulu yang berkaitan dengan penelitian ini dilakukan oleh William (2019) dengan judul penelitian 'Akta Borgtocht dalam Perjanjian Kredit'. Selain itu, Sukmawati (2020) 
memiliki penelitian yang berkaitan dengan penelitian ini. penelitiannya tersebut membahas tentang Personal Guarante sebagai jaminan utang dengan objek hak tanggungan. Penelitian lain yang berkaitan dengan penelitian ini adalah penelitian yang dilakukan oleh Prasetyawati dan Hanoraga (2015) dengan judul penelitian 'Jaminan Kebendaan dan Jaminan Perorangan sebagai Upaya Perlindungan Hukum bagi Pemilik Piutang'. Minabari, Kalalo, dan Sondakh, (2018) juga melakukan penelitian terkait yang membahasa tentang kedudukan lembaga penjaminan kredit dalam perjanjian kredit di bank.

Berdasarkan uraian latar belakang di atas, penelitian ini dilakukan dengan tujuan mendeskripsikan bagaimana akibat hukum yang timbul dari perjanjian kredit yang melibatkan pihak ketiga sebagai penjamin.

\section{METODE PENELITIAN}

Penelitian ini menggunakan pendekatan yuridis normatif, yaitu dengan mengkaji atau mengalisis bahan hukum sekunder dengan memahami hukum sebagai perangkat peraturan atau norma-norma positif di dalam sistem Perundang-Undangan yang mengatur mengenai kehidupan manusia. Sumber data penelitian ini adalah bahan hukum sekunder yang berkaitan dengan rumusan permasalahan di atas. Dalam penelitian hukum jenis ini, hukum dikonsepkan sebagai kaidah/norma yang merupakan patokan berperilaku manusia yang dianggap pantas (Amirudin \& Asikin, 2010).

Pendekatan yang digunakan dalam penelitian ini adalah pendekatan Undang-Undang dan pendekatan analisis konsep hukum. Pendekatan Undang-Undang dilakukan dengan menelaah semua Undang-Undang dan regulasi yang bersangkutan paut dengan isu hukum yang sedang ditangani (Marzuki, 2015). Pendekatan analisis konsep hukum adalah pendekatan yang beranjak dari pandangan-pandangan dan doktrin-doktrin yang berkembang di dalam ilmu hukum. Dengan mempelajari pandangan-pandangan dan doktrin-doktrin di dalam ilmu hukum, peneliti akan menemukan ide-ide yang melahirkan pengertian-pengertian hukum, konsep-konsep hukum, dan asasasas hukum yang relevan dengan isu yang dihadapi. Data yang sudah terkumpul dianalisis menggunakan metode kualitatif dan kemudian disajikan secara deskriptif.

\section{HASIL DAN PEMBAHASAN}

\section{Akibat Hukum yang Timbul dari Perjanjian Kredit yang Melibatkan Pihak Ketiga sebagai Penjamin}

Pada dasarnya subjek-subjek dalam perjanjian terdiri dari pihak kreditur dan debitur. Pihak kreditur berhak atas pemenuhan prestasi sedangkan debitur berkewajiban memenuhi tuntutan prestasi kreditur. Dengan demikian, pihak kreditur sangat menghendaki agar perjanjian dapat dipenuhi secara sempurna dengan sukarela sesuai dengan isi perjanjian yang dimaksud oleh para pihak. Namun kehendak kreditur tidak dapat berjalan sebagai mana mestinya seperti yang dikehendaki oleh setiap kreditur sebab kemungkinan dapat terjadi atau lalai untuk memenuhi kewajiban-kewajiban itu. Oleh karena itu, kelalaian debitur yang tidak memenuhi kewajibannya untuk berprestasi adalah kesalahan debitur. Terhadap keadaan seperti ini yang keadaan dimana seorang debitur tidak dapat memenuhi prestasi kepada kreditur karena kesalahan debitur disebut dengan wanprestasi (Badrulzaman, 2001). Sedangkan debitur yang tidak memenuhi kewajiban bukan karena kesalahannya, melainkan karena keadaan yang memaksa sehingga debitur tidak berprestasi disebut dengan overmatch.

Menurut Undang-undang ada 3 (tiga) unsur yang harus dipenuhi untuk keadaan yang memaksa itu:

1. Tidak memenuhi prestasi

2. Ada sebab yang terletak diluar kesalahan debitur.

3. Faktor penyebab itu tidak diduga sebelumnya dan tidak dapat dipertanggungjawabkan kepada debitur.

Namun yang penting harus diperhatikan bahwa wanprestasi tidak dengan sendirinya ada, melainkan terlebih dahulu dinyatakan lalai. Dalam pasal 1243 KUHPerdata, yang mengatakan:

"Penggantian biaya, rugi dan bunga karena tidak dipenuhinya suatu perikatan, barulah mulai diwajibkan apabila debitur setelah dinyatakan lalai memenuhi perikatannya, tetap melalaikannya, atau jika sesuatu yang harus diberikan atau dibuatnya, hanya dapat diberikan atau dibuat dalam tenggang waktu yang telah dilampaukannya". 
Jadi, maksud "Berada dalam keadaan lalai" ialah peringatan atau pernyataan dari kreditur tentang saat selambat lambatnya debitur wajib memenuhi prestasi. Apabila saat ini dilampauinya, maka debitur ingkar janji (wanprestasi). Adapun kewajiban-kewajiban yang dimaksud sesuai dengan ketentuan pasal 1c Undang-Undang pokok Perbankan, dimana kewajiban melunasi piutang setelah jangka waktu tertentu dengan Bunga yang ditetapkan adalah kewajiban pokok penerima kredit yang ditentukan lagi secara terperinci dalam model-model perjanjian kredit.

Kenyataan di dalam praktek perjanjian kredit akibat dari keadaan yang dikehendakinya, debitur harus menerima sebagai suatu keadaan. Jadi, suatu saat apabila debitur tidak memenuhi kewajiban yang tercantum dalam perjanjian kredit, tidak ada tempatnya kalau debitur mengemukakan alasanalasan tentang keberatannya akan syarat-syarat perjanjian kredit yang telah disetujui. Hal ini bisa terjadi karena dengan adanya tindakan penandatanganan dari blanko perjanjian kredit, maka pihak debitur secara tidak diam-diam sudah setuju terhadap petunjuk dan peraturan bank. Oleh karena itu, apabila debitur lalai dalam memenuhi kewajibannya dalam mengembalikan kredit sesuai dengan perjanjian atau sama skali tidak memenuhi kewajiban, debitur dinyatakan wanprestasi.

Dengan wanprestasinya debitur, maka pihak kreditur dihadapkan pada kesulitan kemungkinan akan mengalami kerugian. Logisnya adanya ketentuan pokok pasal 24 Undang-undang Pokok Perbankan yang melarang adanya pemberian kredit tanpa jaminan. Bagi debitur wanprestasi bukan berarti tidak memiliki kekayaan atau tidak mampu membayar juga kemungkinan karena itikad buruk, dimana debitur tidak mau melakukan prestasi. Adapun dalam kata apabila ia ditagih, mengandung pengertian bahwa perjanjian penanggungan merupakan perjanjian penanggungan merupakan perjanjian accessoir. Jadi, dalam hal debitur wanprestasi kreditur tidak mesti menuntut penjamin terlebih dahulu. Untuk memenuhi hutang debitur, kreditur akan menjual barang-barang jaminan debitur. Apabila hasil penjualan tersebut mencukupi untuk pelunasan hutang-hutang debitur, tanggung jawab penjamin dihapus. Sedangkan bila dari hasil penjualan barang jaminan belum mencukupi, maka terhadap sisa hutang debitur barulah kreditur akan menuntut penjamin. Pada dasarnya perjanjian penanggungan bahwa kreditur mengikat seorang penanggung (penjamin) untuk pemenuhan pembayaran serupa sejumlah uang (Sofwan, 1981).

Maka dari itu seorang penjamin harus memenuhi syarat-syarat seperti tercantum pada pasal 1827 KUHPerdata, yang berbunyi:

"Si berhutang yang diwajibkan memberikan seorang penanggung, harus memajukan seorang

yang mempunyai kecapakan untuk mengikat dirinya, yang cukup mampu untuk memenuhi perikatannya, dan yang berdiam di wilayah Indonesia"

Berdasarkan kenyataan-kenyataan tersebut, untuk lebih meyakinkan kreditur akan keamanan pengembalian perjanjian yang diberikan kepada debitur, diperlukan keterikatan pihak ketiga sebagai pengganti kedudukan debitur yang menjamin pengembalian pinjaman apabila debitur wanprestasi. Secara yuridis sekalipun tanggung jawab penjamin adalah subsidair, penjamin dapat digugat berdasarkan pada perjanjian yang telah disepakati untuk melaksanakan kewajiban-kewajibannya. Dengan demikian, apabila dikehendaki oleh kreditur gugatan dapat dilakukan pada penjamin dan penjamin wajib memenuhi akibat dari perjanjian penanggungan tersebut.

Sedangkan dalam pasal 1825 KUHPerdata menyebutkan bahwa:

"Penanggungan yang tidak terbatas untuk suatu perikatan pokok, meliputi segala akibat hutangnya, bahkan terhitung biaya-biaya gugatan yang dimajukan terjadap si berhutang utama, dan terhitung pula segala biaya yang dikeluarkan setelah si penanggung hutang diperingatkan hal itu".

Dengan demikian apabila penjamin tidak terbatas, hanya ada perjanjian pokok, berarti tanggung jawab penjamin akan meliputi segala kewajiban debitur termasuk segala kewajiban yang timbul akibat melekat pada perjanjian pokok, yaitu "Perjanjian antara kreditur dengan debitur". Namun di dalam akta perjanjian penanggung tidak secara tegas dicantumkan tentang beberapa bagian tanggung jawab yang mesti ditanggung oleh penjamin. Dengan demikian, penjamin dianggap bertanggung jawab atas keseluruhan dari hutang pokok yang meliputi segala akibat hutang debitur termasuk biayabiaya penuntutan, bunga dan kerugian-kerugian yang di timbulkan olehnya (pasal 1825 KUHPerdata).

Persoalan tentang hukum jaminan baik yang menyangkut jaminan kebendaan maupun jaminan pihak ketiga telah lama mendapat perhatian di Negara kita. Sehubungan dengan keperluan akan adanya hukum jaminan bagi masyarakat yang kebutuhannya semakin luas, maka sudah selayaknya untuk membentuk suatu hukum jaminan yang bersifat Nasional. Di dalam pasal 1131 KUHPerdata menerangkan bahwa segala kebendaan si berhutang, baik yang bergerak maupun yang tidak bergerak, 
baik yang sudah ada maupun yang baru aka nada, di kemudian hari akan menjadi tanggungan untuk segala perikatan pihak ketiga. Meskipun telah ditentukan demikian, jaminan secara umum ini sering dirasakan kurang cukup dan kurang aman oleh pihak kreditur karena kekayaan atau harta benda debitur pada suatu waktu bisa musnah dan habis. Disamping itu, juga jaminan secara umum ini diberlakukan untuk semua kreditur-kreditur, sehingga kalau ada lebih dari satu kreditur ada kemungkinan bahwa seorang kreditur akan tidak mendapat bagian dari jaminan yang tersedia apabila pihak Debitur Wanprestasi.

Keberadaan lembaga jaminan kredit yang ada dalam masyarakat mempunyai tugas melancarkan dan mengamankan pemberian kredit. Jadi, jaminan yang baik/ideal adalah (Harsono, 1996):

a) Yang dapat secara mudah membantu perolehan kredit itu oleh pihak yang memerlukan.

b) Yang tidak melemahkan potensi (kekuatan sipencari kredit untuk melakukan/meneruskan usahanya.

c) Yang memberikan kepastian kepada si pemberi kredit, dalam arti bahwa jaminan setiap waktu tersedia untuk dieksekusi, yaitu bila perlu dapat muda diuangkan untuk melunasi hutangnya si penerima (pengambil) kredit.

Sehubungan dengan adanya kemungkinan tidak cukupnya jaminan debitur tersebut, maka sering kali seorang kreditur meminta kepada debiturnya berupa jaminan khusus. Jaminan khusus ini dapat berupa jaminan kebendaan dan juga jaminan perorangan. Yang dimaksud dengan jaminan penanggungan atau disebut juga dengan borgtocht yaitu pihak ketiga yang menjamin hutang orang lain dan pasti akan dibayar pada waktu yang telah ditentukan. Dalam hal ini pihak ketiga (orang atau badan hukum) atau Borg, sedangkan persetujuan yang menimbulkan adanya Borg ini disebut dengan borgtocht (Harsono, 1996).

Jaminan perorangan atau borgtocht menurut pasal 1820 KUHPerdata, bahwa penanggungan adalah suatu perjanjian dengan mana seorang pihak ketiga, guna kepentingan si berpiutang, mengikatkan diri untuk memenuhi perikatan si berutang, manakala orang ini sendiri tidak memenuhinya. Menurut Bahsan (2002), jaminan adalah segala suatu yang diterima kreditur dan diserahkan debitur untuk menjamin suatu hutang-piutang dalam masyarakat. Sedangkan menurut (Poestoko, 2006), jaminan adalah sesuatu yang diberikan kepada kreditur untuk menimbulkan keyakinan bahwa debitur akan memenuhi kewajiban yang dapat dinilai dengan uang yang timbul dari suatu perikatan."

Kemudian untuk mempermudah mendapatkan gambaran mengenai jaminan kredit penanggungan maka akan dikemukakan contoh sebagai berikut: Misalnya si 'A' (Kreditur) meminjamkan uang kepada si 'B' (Debitur) namun si 'A' beranggapan bahwa jaminan si ' $B$ ' kurang dapat memenuhi pelunasan hutangnya, sehingga si ' $A$ ' meminta agar si ' $B$ ' mencari seorang penanggung. Kemudian si ' $\mathrm{C}$ ' sebagai pihak ketiga (Penanggung) menjamin bahwa hutang si ' $\mathrm{B}$ ' yang dibuat dalam suatu perjanjian kepada si ' $\mathrm{A}$ ' Pasti Akan dibayar pada waktu yang telah ditentukan. Jadi dalam hubungan hukum ini si ' $\mathrm{C}$ ' adalah disebut dengan Borg. Persetujuan atau perjanjian yang menimbulkan adanya 'borg' ini disebut dengan 'borgtocht' atau perjanjian penanggungan.

Mengingat sifat dari jaminan perorangan ini, Sofwan (1981) mengemukakan bahwa ditinjau dari sifat perjanjian penanggungan tergolong pada jaminan yang bersifat perorangan, perlu adanya orang pihak ketiga atau badan hukum yang menjamin memenuhi perhutangan manakala debitur wanprestasi. Pada jaminan yang telah bersifat penanggungan demikian pemenuhan prestasi hanya dapat dipertahankannya terhadap orang-orang tertentu yaitu si debitur atau penanggungannya.

\section{SIMPULAN DAN SARAN \\ Simpulan}

Berdasarkan hasil dan pembahasan di atas, simpulan dari penelitian ini adalah akibat hukum yang timbul dari perjanjian kredit yang melibatkan pihak ketiga sebagai penjamin, yaitu: pertama, seorang debitur dapat dituntut oleh penanggung yang telah membayar hutangnya kreditur. Penanggungan itu bisa terjadi dengan sepengetahuan atau tanpa sepengetahuan debitur itu sendiri. Kedua, penanggung mempunyai hak menuntut biaya ganti rugi dan bunga. Ketiga, pihak kreditur dan pihak penanggung harus memperhatikan hak-hak dan kewajiban tertentu. Terakhir, penanggung atau pihak ketiga 
diberikan hak untuk membagi hutangnya, yaitu pada waktu digugat untuk pemenuhan, dapat menuntut bagian-bagian dari pihak mereka sebagai penanggung.

\section{Saran}

Selain simpulan, ada beberapa saran yang perlu disampaikan berdasarkan hasil penelitian ini, yaitu: dalam proses pembuatan perjanjian kredit dengan pihak ketiga sebagai penjamin, hendaknya masingmasing pihak yang membuat kesepakatan harus mengerti terhadap isi. Diharapkan jika debitur wanprestasi, penjamin dalam melunasi hutangnya jangan sampai mengakibatkan konflik bagi seluruh pihak hanya karena alasan mereka yang bersangkutan tidak paham akan hak dan kewajiban mereka masing-masing. Selain itu, telah diketahui bahwa ketentuan dari perjanjian kredit dengan pihak ketiga sebagai penjamin yang berlaku di Indonesia sampai saat ini masih tersebar di beberapa peraturan hukum. Dari kenyataan ini disarankan untuk meninjau kembali keberadaan dari jaminan pihak ketiga (borgtocht) sebagai jaminan kredit dan agar membentuk peraturan khusus yang mencakup perjanjian kredit dengan pihak ketiga sebagai penjamin sesuai kondisi saat ini.

\section{DAFTAR PUSTAKA}

Aman, E. P. T. (1985). Kredit Perbankan: Suatu Tinjauan Yuridis.

Amirudin, \& Asikin, Z. (2010). Pengantar Metode Penelitian Hukum.

Badrulzaman, M. D. (2001). Kompilasi Hukum Perikatan.

Bahsan, M. (2002). Penilaian Jaminan Kredit Perbankan Indonesia.

Harsono, S. (1996). Sambutan Menteri Agraria/Kepala BPN pada Seminar Hak Tanggungan atas Tanah dan Benda-benda yang Berkaitan dengan Tanah. Bandung: Fakultas Hukum UNPAD.

Marzuki, P. M. (2015). Penelitian Hukum.

Minabari, A., Kalalo, M. E., \& Sondakh, J. (2018). Kedudukan Lembaga Penjaminan Kredit dalam Perjanjian Kredit di Bank. Lex Et Societatis, 6(3), 101-107.

Poestoko, H. (2006). Parate Executie Obyek Hak Tanggungan (Universitas Airlangga).

Prasetyawati, N., \& Hanoraga, T. (2015). Jaminan Kebendaan dan Jaminan Perorangan sebagai Upaya Perlindungan Hukum bagi Pemilik Piutang. JSH: Jurnal Sosial Humaniora, 8(1), 120-134.

Sofwan, S. S. M. (1981). Hukum Perdata: Hak Jaminan atas Atas.

Sofwan, S. S. M., \& Indonesia. Badan Pembinaan Hukum Nasional. (1980). Hukum Jaminan di Indonesia, Pokok-Pokok Hukum Jaminan dan Jaminan Perorangan.

Sukmawati, M. N. (2020). Personal Guarante terhadap Perjanjian Kredit dengan Jaminan Hak Tanggungan. Airlangga Development Journal, 3(1), 1-18.

William, G. V. (2019). Akta Borgtocht dalam Perjanjian Kredit. Jurnal Media Hukum Dan Peradilan, 5(1), 5061. 